\title{
TIPOLOGI MOTIF CAP TANGAN PRASEJARAH DI LEANG UHALLIE, KABUPATEN BONE, SULAWESI SELATAN
}

\author{
Irsyad Leihitu \\ Alumnus Program Sarjana Program Studi Arkeologi Fakultas IImu Pengetahuan Budaya Universitas Indonesia, \\ irsyad.leihitu@gmail.com
}

DOI: $10.17510 /$ paradigma.v6i2.98

\section{ABSTRACT}

This article discusses the typology of a hand stencil pattern cave painting located in Leang Uhallie, Bone district, South Sulawesi. Irving Rouse's taxonomy classification methods were used to find the typology of the hand stencil pattern. This study shows that there are three forms of hand stencil with 21 variants. This typologycal study of the hand stencil also shows the dominant and the unique pattern form of Leang Uhallie.

\section{KEYWORDS}

Typhology; rock arts; hand stencil motif; Uhallie Cave; classification.

\section{Pendahuluan}

Pola perkembangan kehidupan manusia prasejarah pada masa lalu, dari nomaden ke semi menetap, secara tidak langsung telah menghasilkan sebuah kebudayaan baru, khususnya dalam bidang seni, yaitu kelahirankarya seni tertua berupa gambar cadas (rock art). Gambar cadas adalah sebuah lukisan atau pahatan yang dibuat pada batu alamiah yang masih melekat pada batuan induknya (Rosenfeld 1988, 1-2). Pada umumnya gambar cadas memiliki berbagai macam motif dan bentuk, antara lain gambar antropomorfis, baik motif manusia maupun bagian pada organ tubuh manusia, seperti cap tangan ataupun kaki, mahkluk mitologis, fauna, flora, benda (senjata, peralatan sehari-hari, dan artefak lain), motif garis, serta berbagai bentuk lain yang berupa simbol tertentu (Kosasih 1983, 162; 1999, 5).

Di antara motif gambar cadas di atas, yang paling sering ditemukan antara lain motif cap tangan yang akan dibahas dalam tulisan ini. Motif cap tangan atau yang disebut hand stencil ini dibuat oleh manusia pada masa lalu dengan cara merentangkan jari-jari tangan dan menempelkannya ke permukaan dinding gua. Pewarnaan motif cap tangan menggunakan cat yang terdiri atas beberapa warna, tetapi yang terkenal adalah warna merah, hitam, dan putih. Teknik pembuatan motif cap tangan dua macam, yaitu teknik negative hand stencil dengan cara disemprotkan dan teknik positive hand stencil yang dilakukan dengan cara melumuri warna pada telapak tangan yang kemudian ditempelkan pada permukaan dinding gua (Permana 2014, 5-6). 
Penelitian mengenai gambar cadas, khususnya motif cap tangan, sangat penting dilakukan untuk merekonstruksi kebudayaan manusia prasejarah. Penelitian ini bertujuan untuk mendeskripsikan ragam bentuk motif tangan yang digambarkan oleh manusia pendukung kebudayaan gambar cadas di Leang Uhallie.

Leang Uhallie merupakan situs gua prasejarah yang memiliki kandungan gambar cadas sangat bervariasi, dari motif tangan, motif hewan, sampai motif geometris. Berbagai motif itu tersebar di dinding dan langit-langit gua. Penelitian ini berusaha untuk menyusun tipologi dari 139 motif cap tangan yang digambarkan di Leang Uhallie. Usaha itu tentu sangat penting mengingat Leang Uhallie merupakan situs gua prasejarah yang baru ditemukan dan belum banyak tulisan yang membahasnya.

\section{Metode}

Melalui hasil observasi berbagai motif cap tangan yang ditemukan di Leang Uhallie, diketahui bahwa terdapat variasi bentuk. Oleh karena itu, untuk menyusun tipologi motif cap tangan, digunakan metode klasifikasi. Klasifikasi merupakan sebuah alat bantu yang sangat umum dalam penelitian ilmiah, begitu juga dalam ilmu arkeologi. Para ahli pada umumnya menggunakan klasifikasi untuk memudahkan proses analisis data penelitian. Klasifikasi didefinisikan sebagai sebuah proses penyederhanaan data yang acak menjadi mengelompok atau menggolongkan data berdasarkan kesamaan karakter yang dimilikinya (Sharer dan Ashmore 2003, 295; Beck dan Jones 1989, 224). Perlu diketahui bahwa tahap klasifikasi merupakan awal dari analisis sehingga hasil dari klasifikasi bukanlah akhir dari penelitian.

Pengklasifikasian dalam penelitian ini menggunakan metode klasifikasi yang dikemukakan oleh Irving Rouse. Pada umumnya klasifikasi Rouse terdiri atas dua jenis, yaitu klasifikasi analitis dan klasifikasi taksonomis. Klasifikasi analitis digunakan untuk mengetahui mode yang dimiliki oleh data, mode sendiri dapat berupa mode hasil budaya dan mode yang bersifat alamiah. Selain itu, mode juga terdiri dari mode konseptual dan mode prosedural yang disesuaikan dengan tujuan penelitian. Sementara itu, klasifikasi taksonomis memfokuskan pada pencarian berbagai tipe pada data. Tipe itu didapatkan berdasarkan pemilihan atribut yang dimiliki oleh data (Rouse 1971, 315). Klasifikasi yang digunakan dalam analisis motif tangan ini adalah klasifikasi taksonomis. Klasifikasi taksonomis ini bertujuan untuk menghasilkan tipe berdasarkan dua atau lebih atribut yang telah ditentukan oleh peneliti ini dalam tujuan penelitian (Rouse 1971, 315-318).

Dalam tulisannya, Rouse (1971, 315-318) menyebutkan bahwa dalam klasifikasi taksonomis dikenal beberapa istilah, yaitu (1) kategori, (2) tipe, (3) subtipe, (4) sub-subtipe, (5) dan varian. Kategori merupakan sebuah sistem dalam klasifikasi yang merupakan penggolongan dari satuan alat klasifikasi, contohnya adalah pada klasifikasi motif tangan. "Kategori" 1 merupakan atribut bentuk yang berupa bentuk umum dari motif tangan yang kemudian dijadikan satuan "tipe", yaitu ( $\mathrm{Tt}$ ) telapak tangan, (TsP) telapak sampai pergelangan, dan (TsL) telapak sampai lengan. Melihat kemungkinan ada perbedaan sisi tangan pada setiap bentuknya, atribut sisi tangan dijadikan "kategori" 2 yang merupakan satuan "subtipe" yaitu (1) kanan dan (2) kiri. Selanjutnya, "kategori" 3 yang merupakan atribut ukuran yang dimiliki tiap motif tangan yang merupakan satuan dari "sub-subtipe", yaitu (B) besar dan (K) kecil, dan yang terakhir adalah atribut arah hadap atau orientasi yang merupakan "kategori" 4 dan sebagai satuan "varian" yaitu (a) atas, (b) kanan, (c) bawah, dan (d) kiri. Dasar klasifikasi ini dirumuskan dengan menentukan atribut kuat atau yang paling menonjol pada objek. Dalam hal ini, atribut yang paling kuat adalah bentuk tangan, yang kedua adalah atribut sisi tangan, kemudian atribut ukuran, dan terakhir atribut orientasi. Atribut sisi tangan lebih menonjol dibandingkan atribut ukuran,karena setiap motif tangan selalu menunjukkan sisi tangan yang jelas. Sementara itu, atribut ukuran tidak terlalu signifikan karena perbedaan ukuran tangan yang besar dan kecil hanya sedikit. 


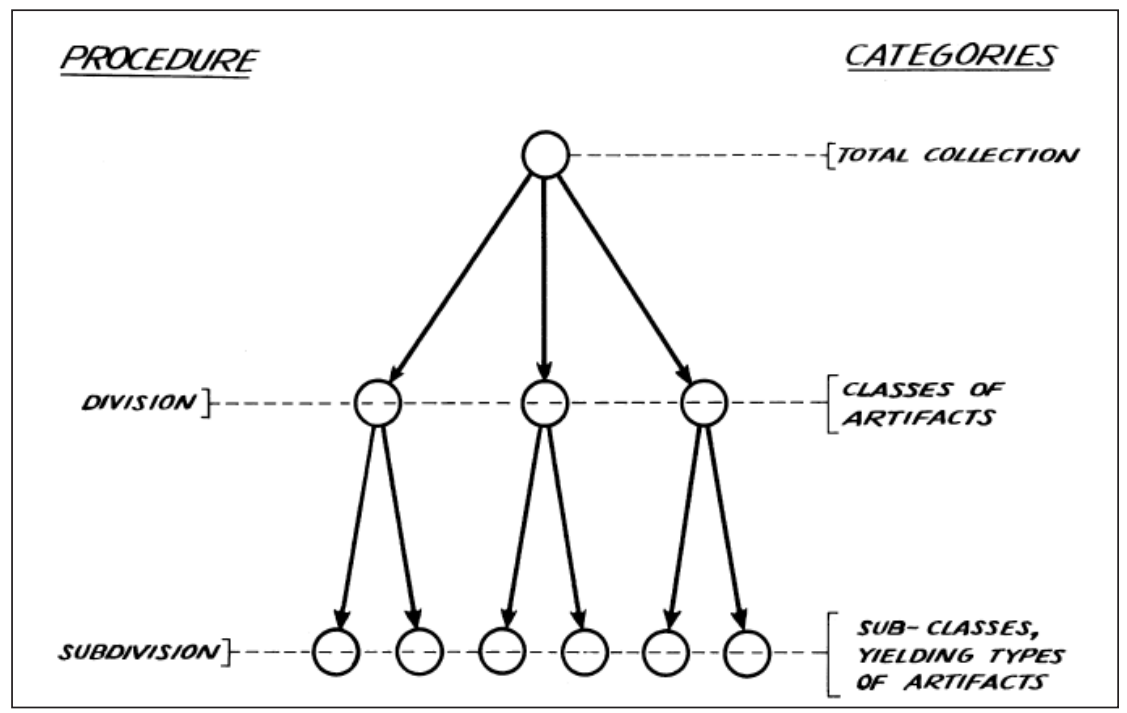

Bagan 1. Klasifikasi Taksonomi Rouse (Rouse, 1971:316)

\section{Hasil dan Pembahasan}

Berikut ini akan dibahas temuan dalam penelitian ini. Akan dibicarakan, pertama situs penelitian, kedua gambar cadas, ketiga analisis bentuk, dan keempat atau terakhir klasifikasi gambar cap tangan.

\subsection{Situs Leang Uhallie}

Secara administratif Leang Uhallie masuk dalam wilayah Dusun Kalukkue, Desa Langi, Kecamatan Bontocani, Kabupaten Bone. Dusun Kalukkue berada di posisi astronomis $05^{\circ} 01^{\prime 2} 2,38^{\prime \prime}$ lintang selatan dan $199^{\circ} 58^{\prime} 7,42^{\prime \prime}$ bujur timur, pada ketinggian sekitar 621 meter di atas permukaan laut.

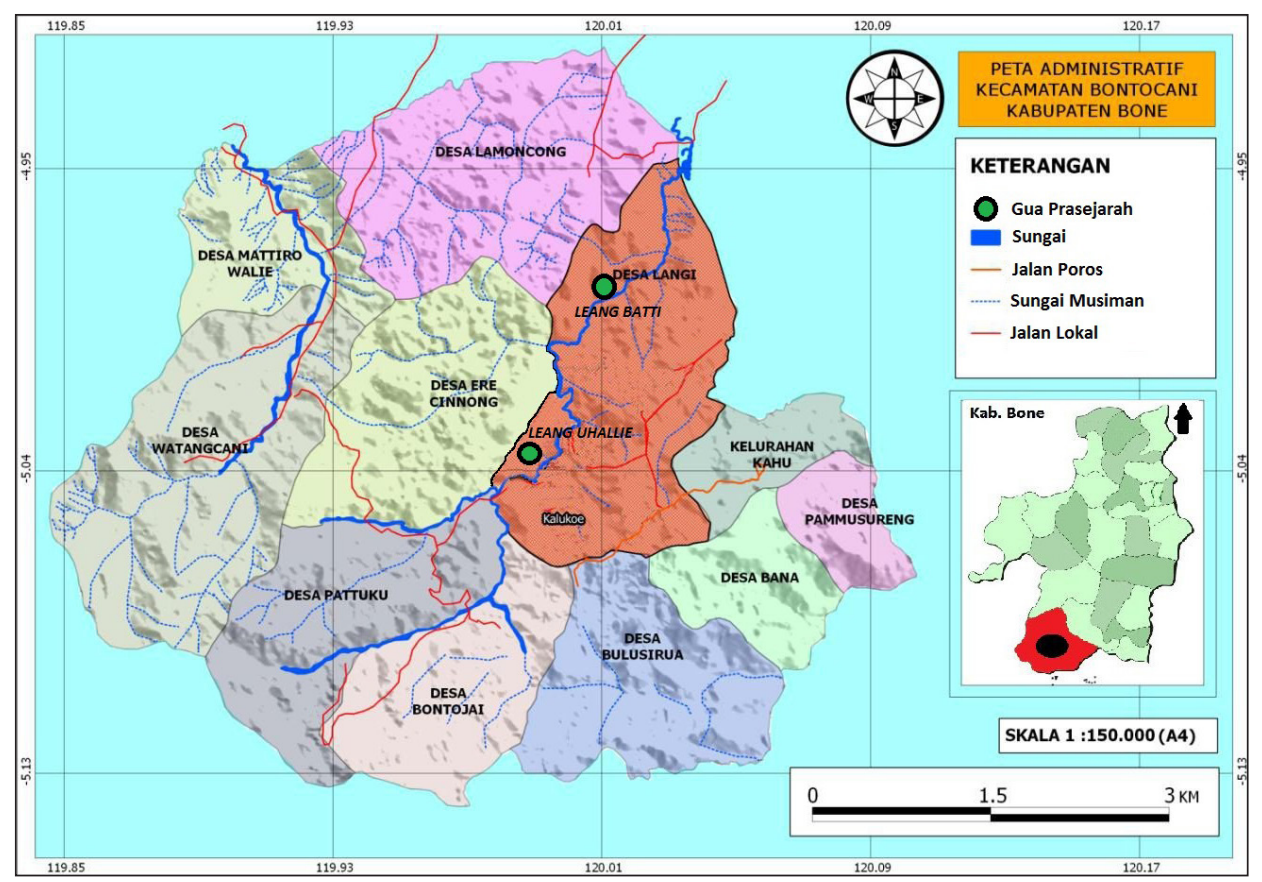

Peta 1. Peta Administrasi Kecamatan Bontocani (Sumber: Dimodifikasi dari Arizona Rais, 2015). 
Leang Uhallie merupakan sebuah lubang di tebing karst yang terdiri dari dua buah ruangan. Kedua ruangan terhubung satu sama lain, baik Ruang 1 maupun Ruang 2 sama-sama memiliki mulut gua yang menjadi pintu masuk dan keluar ruangan. Secara keseluruhan terdapat tiga mulut gua di Leang Uhallie, yaitu dua di Ruang 1 dan satu di Ruang 2. Di gua itu, pintu masuk utama adalah mulut gua paling besar yang terdapat di ruangan satu dan di tengah mulut gua yang lain. Mulut gua yang dijadikan pintu utama belum tentu merupakan pintu utama yang digunakan oleh manusia prasejarah pada masa lalu. Berhubung mulut gua yang menjadi pintu masuk di gua ini cukup tinggi (sekitar 3 meter), untuk mencapainya, digunakan tangga yang dibuat dari bambu.

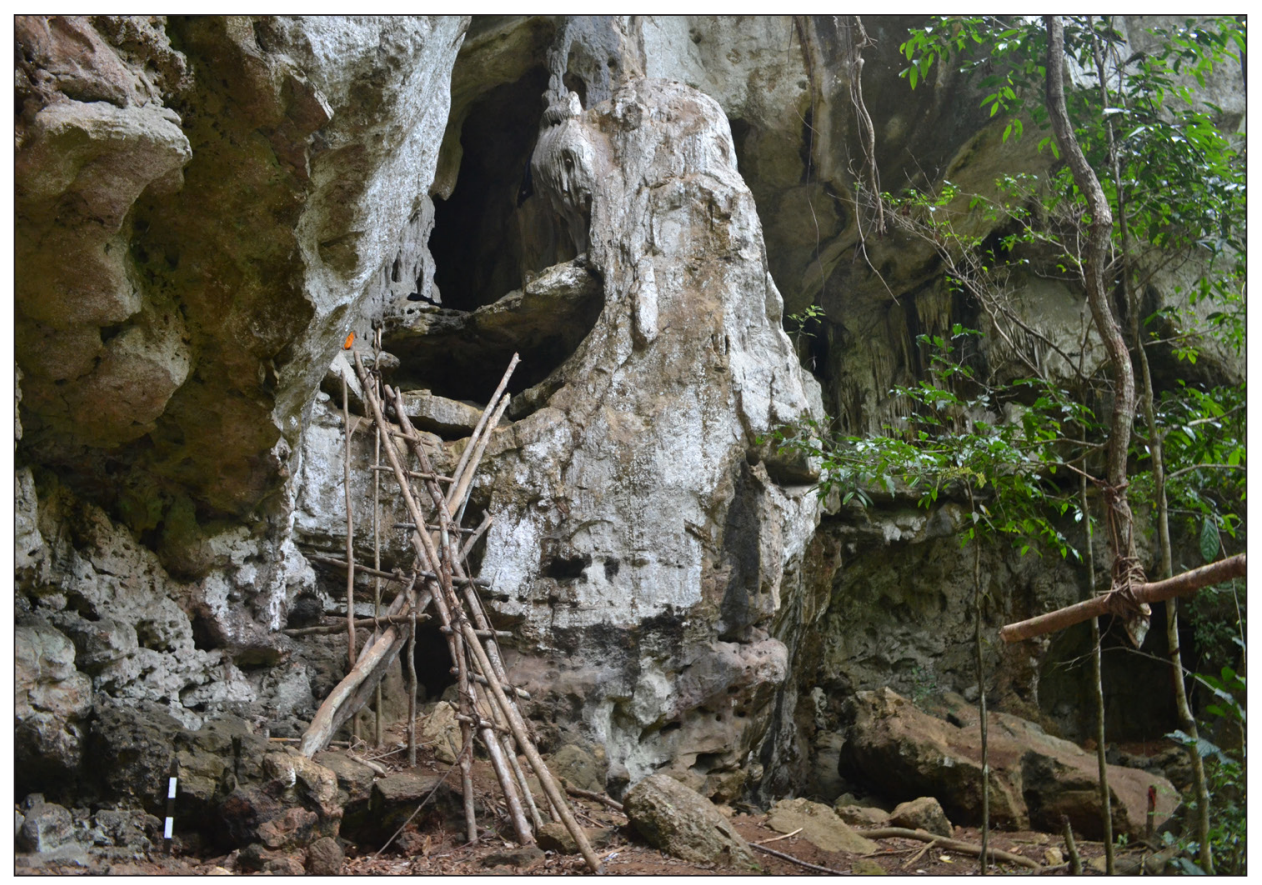

Gambar 1. Mulut Gua Leang Uhallie (Foto Pribadi).

\subsection{Gambar Cap Tangan}

Leang Uhallie memiliki gambar cadas berupa motif cap tangan yang berjumlah 139 buah yang tersebar di dinding dan langit-langit gua. Dalam penelitian ini, berbagai gambar itu dikelompokkan menjadi delapan panil. Panil 1 yang berada di dinding barat Ruang 1 dengan ketinggian rata-rata $200 \mathrm{~cm}$ dan memiliki enam motif tangan yang digambarkan memanjang secara horizontal, kemudian Panil 2 yang berada di dinding utara Ruang 1 dengan ketinggian rata-rata $100 \mathrm{~cm}$ dan memiliki gambar cadas berupa 32 motif tangan yang digambarkan mengumpul di tengah panil, serta Panil 3 yang berada di dinding utara Ruang 1 dengan ketinggian rata-rata $90 \mathrm{~cm}$ dan memiliki gambar cadas berupa motif tangan sebanyak 20 motif yang digambarkan memanjang mengikuti bentuk panil. 


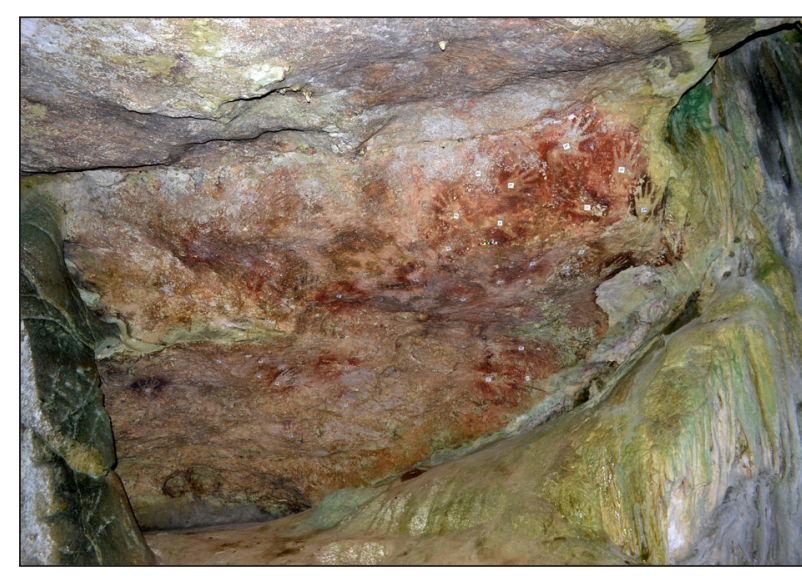

Gambar 2. Gambar Cadas di Panil 2 Leang Uhallie (Foto Pribadi).

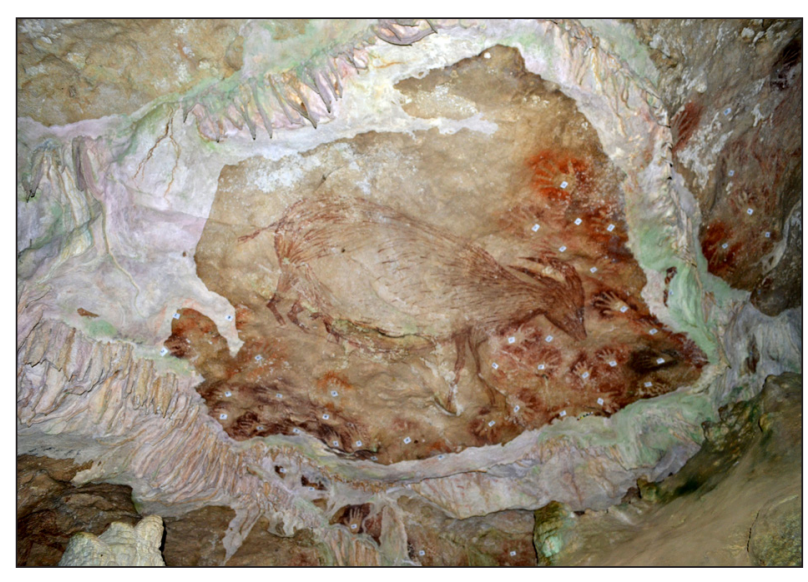

Gambar 3. Gambar Cadas di Panil 4 Leang Uhallie (Foto Pribadi).

Panil 4 yang berada di dinding timur Ruang 1 memiliki ketinggian rata-rata $110 \mathrm{~cm}$ dengan gambar cadas berupa motif tangan sebanyak 38 motif yang mengumpul di sisi kanan panil, kemudian Panil 5 yang berada di dinding timur Ruang 1 dengan ketinggian rata-rata $115 \mathrm{~cm}$ dan memiliki gambar cadas berupa motif tangan sebanyak 20 motif tangan yang tersebar di panil, Panil 6 terletak di dinding selatan Ruang 1 dengan ketinggian rata-rata $342 \mathrm{~cm}$ yang memiliki gambar cadas sebanyak satu motif tangan, Panil 7 terletak di langit-langit utara Ruang 1 dengan ketinggian rata-rata $200 \mathrm{~cm}$ yang memiliki gambar cadas sebanyak tiga motif tangan, dan yang terakhir adalah Panil 8 terletak di langit-langit tengah Ruang 2 yang mempunyai ketinggian rata-rata $450 \mathrm{~cm}$ dari permukaan tanah dan memiliki 18 motif tangan.

Motif cap tangan tersebut pada umumnya memiliki tiga bentuk, yaitu bentuk telapak tangan, telapak sampai pergelangan, dan telapak sampai lengan. Motif itu pada umumnya digambarkan dengan warna merah dan berukuran besar ataupun kecil. Motif cap tangan di Leang Uhallie terdiri dari sisi tangan sebelah kanan dan kiri, dengan orientasi yang menghadap ke atas, kanan, bawah, dan kiri. Atribut yang dijelaskan di atas akan dijadikan acuan dalam proses analisis di bawah ini.

\subsection{Analisis Bentuk}

Untuk melakukan klasifikasi, pada umumnya harus terlebih dahulu mengetahui berbagai atribut yang terdapat di dalam data. Pemilihan atribut bertujuan untuk memudahkan proses pengelompokan data berdasarkan atribut. Oleh karena itu, harus dilakukkan pemilihan atribut pada gambar cadas di Leang Uhallie terlebih dahulu. Perlu diketahui bahwa pemilihan atribut harus memperhatikan atribut kuat dan atribut lemah pada data. Cara itu berguna untuk menggolongkan data berdasarkan atributnya. Berikut ini adalah atribut pada motif tangan dan motif hewan di Leang Uhallie.

\section{- Atribut Bentuk}

Atribut ini merupakan bentuk penggambaran dari motif tangan yang terdiri dari telapak tangan (Tt), telapak sampai pergelangan (TsP), dan telapak sampai lengan (TsL). 


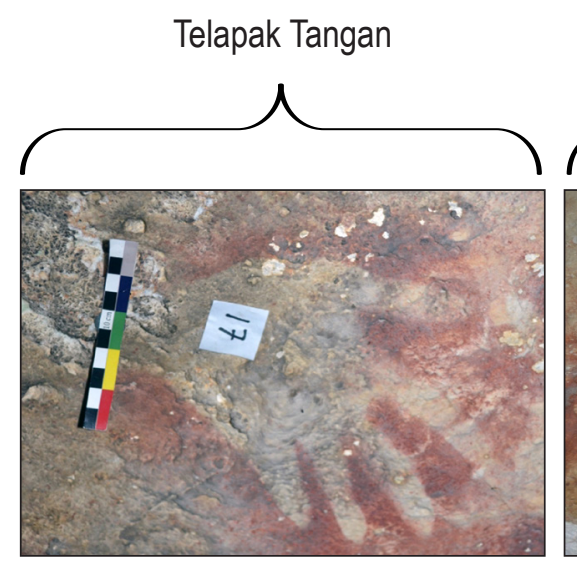

Telapak sampai Pergelangan

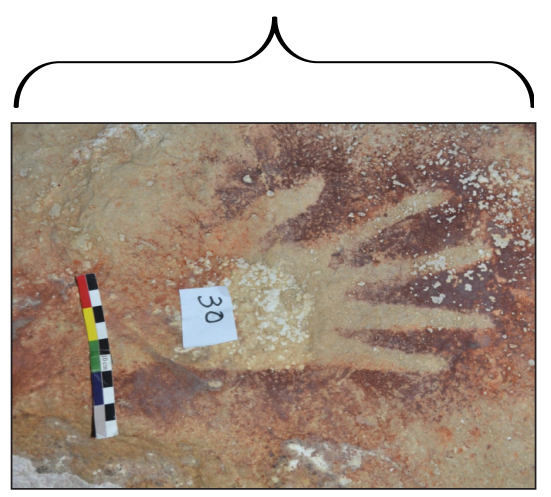

Telapak sampai Lengan

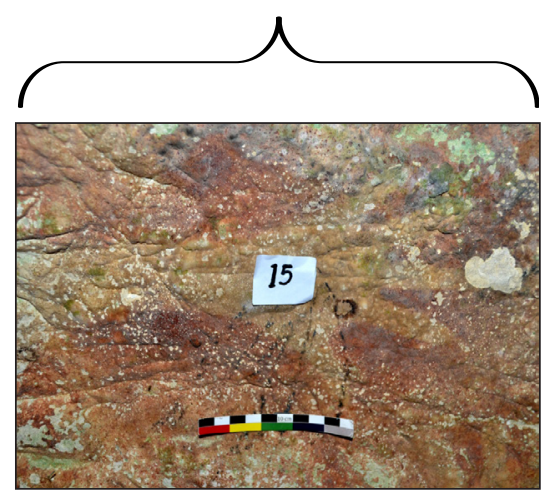

Gambar 4, 5, dan 6. Atribut Bentuk pada Motif Tangan (Foto Pribadi).

Perbedaan ketiga bentuk motif tangan tersebut terlihat dari penggambarannya. Pada motif telapak tangan hanya digambarkan dari ujung jari sampai ke ujung telapak tangan, pada motif telapak sampai pergelangan digambarkan dari ujung jari hingga ke pergelangan tangan, sedangkan pada motif telapak sampai lengan digambarkan dari ujung jari hingga ke bagian lengan tangan.

\section{- Atribut Sisi Tangan}

Atribut sisi tangan merupakan sisi tangan dari motif tangan. Berhubung manusia hanya memiliki dua tangan, dalam atribut ini hanya ada sisi tangan kanan (1) dan sisi tangan kiri (2). Kedua bentuk sisi tangan ini dapat dilihat dengan jelas apabila diperhatikan motifnya dengan teliti. Cara yang paling mudah untuk menentukannya adalah dengan melihat posisi ibu jari. Ibu jari di sebelah kiri menunjukkan bahwa motif itu merupakan tangan kanan, sedangkan ibu jari di sebelah kanan menunjukkan motif yang merupakan tangan kiri.

Motif Tangan Kanan

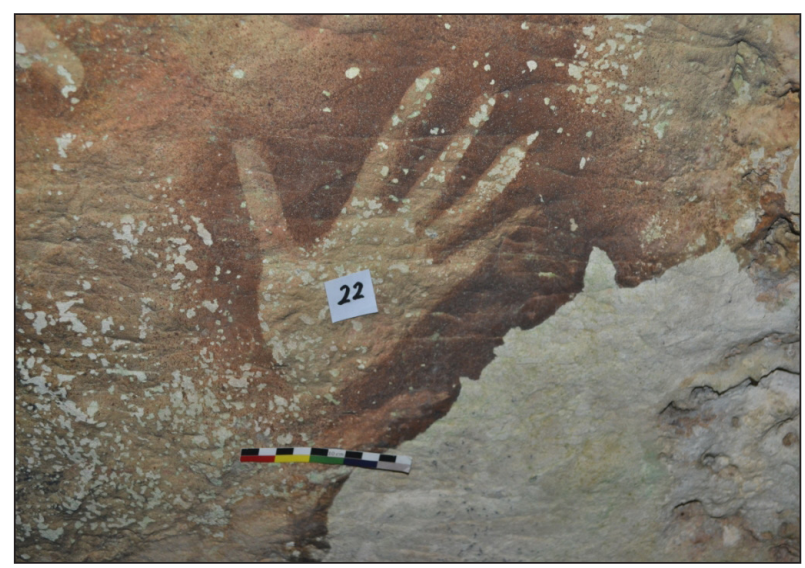

Motif Tangan Kiri

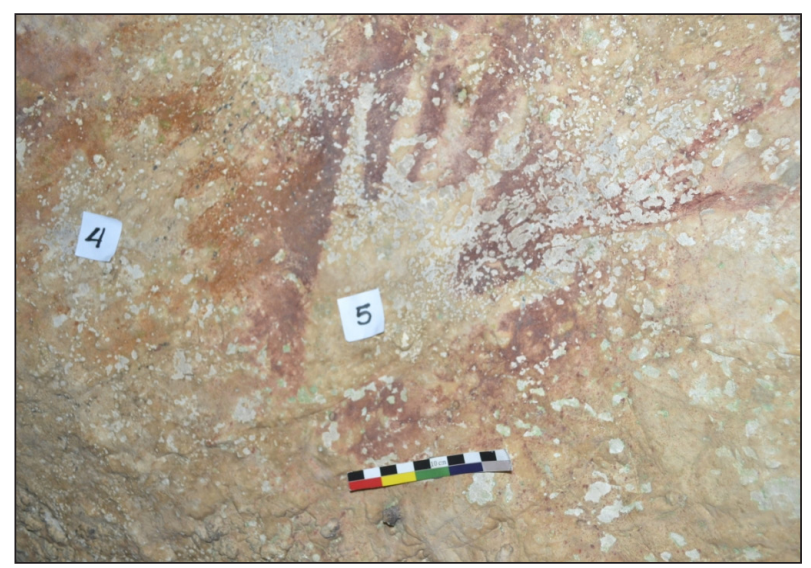

Gambar 7 dan 8. Atribut Sisi Tangan pada Motif Tangan (Foto Pribadi).

\section{- Atribut Ukuran}

Motif tangan memiliki ukuran yang sama dengan tangan manusia. Pada gambar motif tangan ini tidak terdapat pembesaran atau pengecilan meskipun terdiri atas besar $(\mathrm{B})$ dan kecil (K); artinya panjang dan lebarnya merupakan aspek terpenting untuk menentukan ukurannya. Motif tangan yang berukuran besar 
pada umumnya memiliki panjang 11-30 cm dari ujung jari tengah sampai bagian bawah motif dan memiliki lebar 10-15 cm dari ujung ibu jari sampai ke sisi telapak tangan di bawah jari kelingking. Sementara itu, motif tangan yang berukuran kecil panjangnya 8-10 cm dari ujung jari tengah sampai bagian bawah motif dan lebarnya 7-9 cm dari ujung ibu jari sampai ke sisi telapak tangan di bawah jari kelingking.

Besar (Tangan Dewasa)

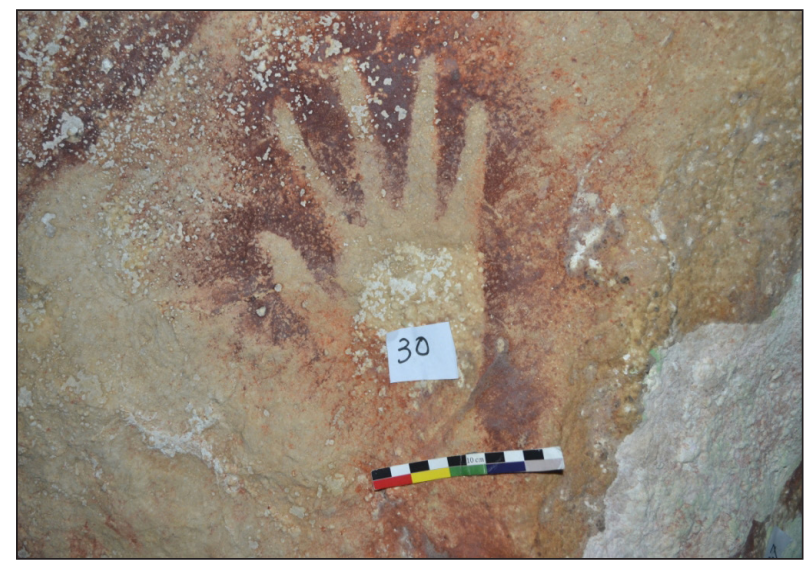

Kecil (Anak-Anak)

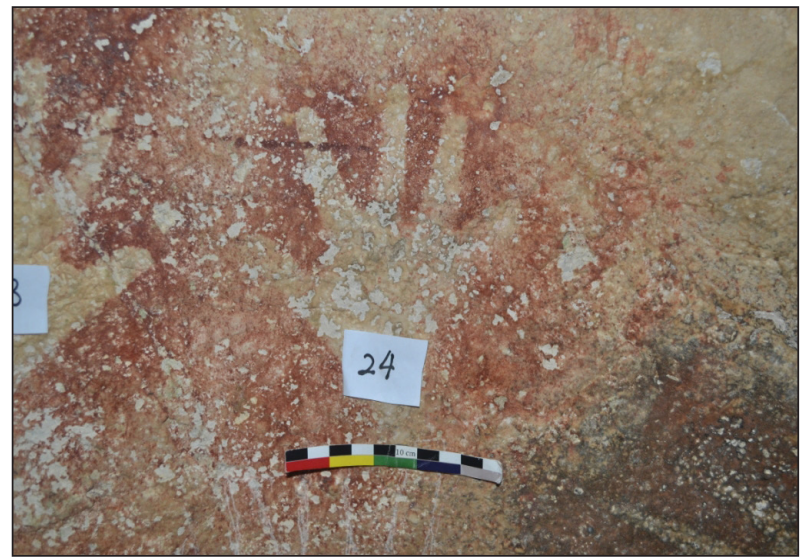

Gambar 9 dan 10. Atribut Ukuran pada Motif Tangan (Foto Pribadi).

\section{- Atribut Orientasi}

Terakhir adalah unsur orientasi, atau arah hadap motif tangan terhadap panil. Orientasi motif tangan di Leang Uhallie terdiri dari (a) atas, (b) kanan, (c) bawah, dan (d) kiri.

\section{Atas}

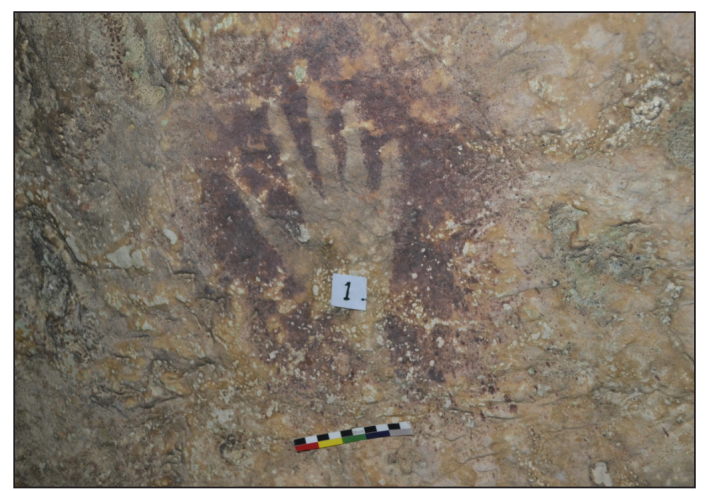

Bawah

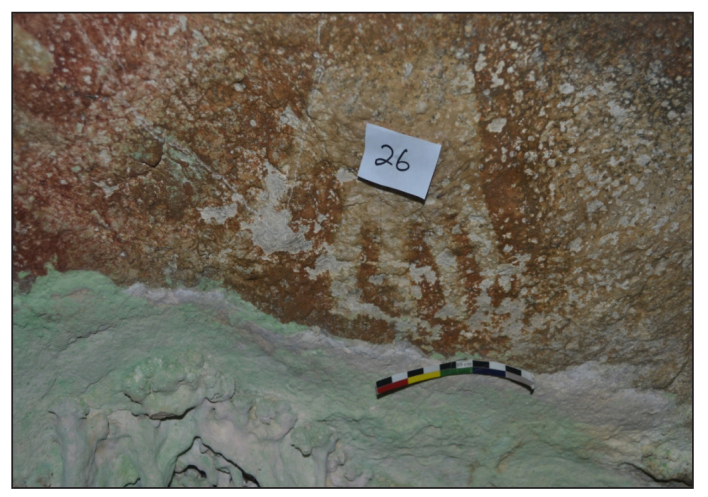

Kanan

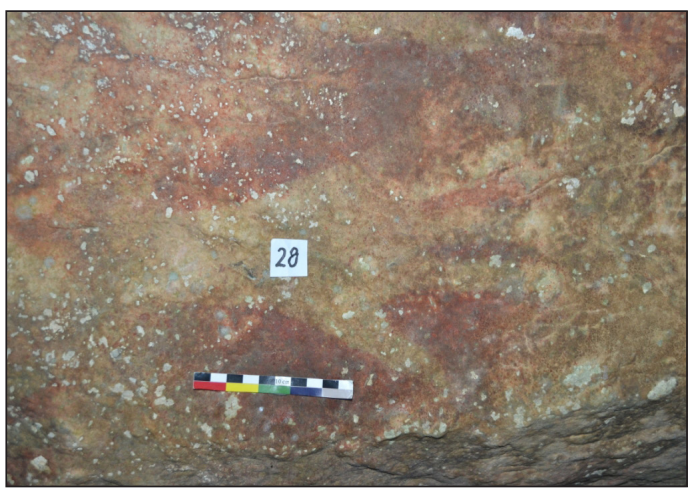

Kiri

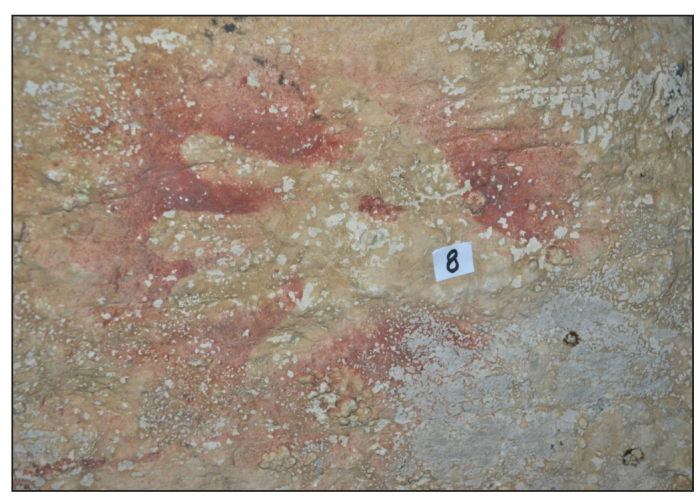

Gambar 11, 12, 13, dan 14. Atribut Orientasi pada Motif Tangan (Foto Pribadi). 
Setelah melakukan analisis bentuk setiap motif tangan, hasilnya adalah variasi bentuk motif tangan yang terdapat di Leang Uhallie. Mengingat bahwa motif tangan yang terdapat di panil cukup banyak, analisis bentuk motif tangan tidak berhenti sampai di sini. Langkah selanjutnya adalah mengelompokkan motif itu berdasarkan kesamaan atributnya, maka diperlukan bantuan metode klasifikasi dengan tujuan untuk memudahkan pengelompokan.

\subsection{Klasifikasi Gambar Cap Tangan}

Dalam tulisannya Rouse (1971,315-318) menyebutkan bahwa dalam klasifikasi taksonomis dikenal beberapa istilah, yaitu adalah (1) kategori, (2) tipe, (3) subtipe, (4) subsubtipe, (5) dan varian. Kategori merupakan sebuah sistem dalam klasifikasi yang merupakan penggolongan satuan alat klasifikasi, contohnya adalah klasifikasi motif tangan. "Kategori 1" merupakan atribut bentuk yang bersifat umum pada motif tangan yang dijadikan satuan "tipe", yaitu (Tt) telapak tangan, (TsP) telapak sampai pergelangan, dan telapak sampai lengan (TsL). Mengingat kemungkinan perbedaan sisi tangan di setiap bentuk, atribut sisi tangan dijadikan "kategori 2" yang merupakan satuan subtipe, yaitu (1) kanan dan (2) kiri. Selanjutnya, adalah "kategori 3". Kategori ini merupakan atribut ukuran tiap motif tangan yang merupakan satuan dari "subsubtipe", yaitu (B) besar dan (K) kecil; dan yang terakhir adalah atribut arah hadap atau orientasi yang merupakan "kategori 4" yang terdiri atas satuan "varian" (a) atas, (b) kanan, (c) bawah, dan (d) kiri.

Dasar klasifikasi tersebut dibuat dengan menentukan atribut kuat atau paling menonjol pada objek. Dalam hal ini, atribut yang paling kuat adalah bentuk tangan, pada urutan kedua adalah atribut sisi tangan, pada urutan ketiga atribut ukuran, dan yang terakhir atribut orientasi. Atribut sisi tangan lebih menonjol dibandingkan atribut ukuran karena setiap motif tangan selalu menunjukkan sisi tangan yang jelas. Sementara itu, atribut ukuran tidak signifikan karena perbedaan ukuran tangan yang besar dan kecil hanya sedikit.

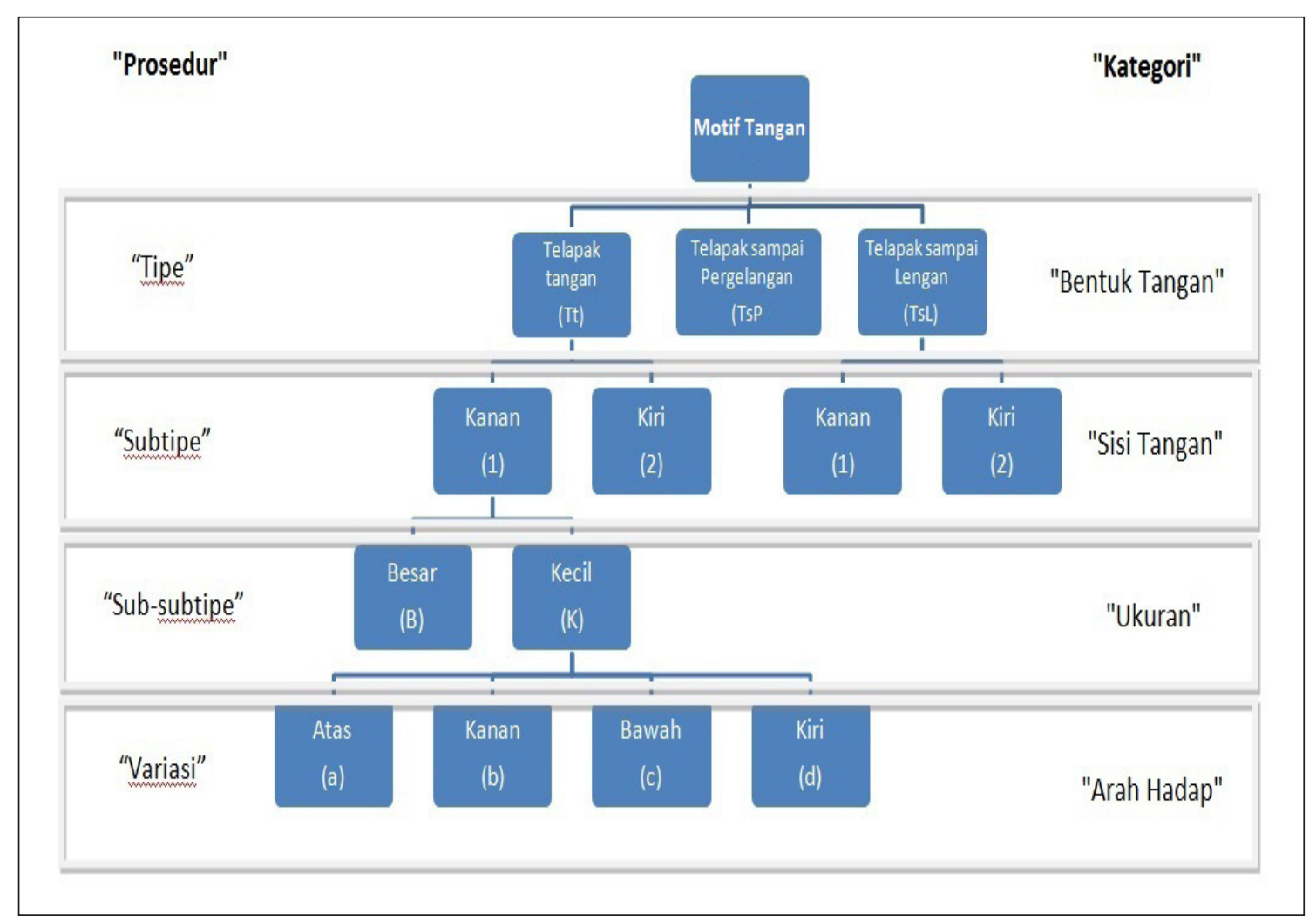

Bagan 2. Klasifikasi Taksonomi Motif Tangan. 
Setiap panil di Leang Uhallie memiliki bentuk motif tangan yang jumlahnya beranekaragam. Kedelapan panil itu, apabila semua atribut bentuk gambarnya digabungkan dalam satu tabel, akan menggambarkan bentuk gambar tangan khas Leang Uhallie. Berikut ini adalah tabel keseluruhan atribut motif tangan yang ada di Leang Uhallie.

\begin{tabular}{|c|c|c|c|c|c|c|c|c|c|c|c|}
\hline \multirow{3}{*}{$\begin{array}{l}\text { Motif } \\
\text { Tangan } \\
\text { Perpanil } \\
\end{array}$} & \multicolumn{11}{|c|}{ Atribut } \\
\hline & \multicolumn{3}{|c|}{ Bentuk } & \multicolumn{2}{|c|}{ Sisi Tangan } & \multicolumn{2}{|c|}{ Ukuran } & \multicolumn{4}{|c|}{ Orientasi } \\
\hline & $\begin{array}{l}\text { Telapak } \\
\text { Tangan }\end{array}$ & $\begin{array}{l}\text { Telapak } \\
\text { sampai } \\
\text { Perge- } \\
\text { langan }\end{array}$ & $\begin{array}{l}\text { Telapak } \\
\text { sampai } \\
\text { Lengan }\end{array}$ & Kanan & Kiri & Besar & Kecil & Atas & Kanan & Bawah & Kiri \\
\hline Panil 1 & 5 & - & - & 4 & 1 & 5 & - & 1 & 2 & - & 2 \\
\hline Panil 2 & 21 & 9 & 1 & 13 & 18 & 28 & 3 & 16 & 8 & 3 & 4 \\
\hline Panil 3 & 18 & - & - & 11 & 7 & 12 & 6 & 12 & 4 & - & 2 \\
\hline Panil 4 & 24 & 7 & - & 15 & 16 & 30 & 1 & 17 & 5 & 3 & 6 \\
\hline Panil 5 & 13 & 5 & 1 & 6 & 13 & 18 & 1 & 7 & 8 & 1 & 3 \\
\hline Panil 6 & 1 & - & - & - & 1 & 1 & - & 1 & - & - & - \\
\hline Panil 7 & 2 & - & - & - & 2 & 2 & - & 2 & - & - & - \\
\hline Panil 8 & 19 & - & - & 11 & 8 & 19 & - & 15 & 3 & - & 1 \\
\hline Jumlah: & 103 & 21 & 2 & 60 & 66 & 115 & 11 & 71 & 30 & 7 & 18 \\
\hline
\end{tabular}

Tabel 1. Motif Tangan Leang Uhallie.

Tabel di atas menunjukkan bahwa motif tangan di Leang Uhallie terdiri atas 103 motif telapak tangan, 21 motif pergelangan tangan, dan 2 motif dengan bentuk lengan. Ke-126 motif tangan itu terdiri atas 60 motif yang merupakan sisi tangan kanan dan 66 motif dengan sisi tangan kiri. Motif telapak tangan di Leang Uhallie pada umumnya berukuran dua macam, yaitu motif berukuran besar, 115 motif dan yang berukuran kecil, 11 motif. Atribut lain adalah orientasi. Gambar cadas yang terdapat di Leang Uhallie memiliki 30 motif yang berorientasi ke kanan, 7 motif ke arah bawah, 18 motif ke kiri, dan 71 motif (terbanyak) yang berorientasi ke atas.

Berdasarkan analisis bentuk motif tangan di Leang Uhallie, ditemukan tiga tipe motif tangan, yaitu telapak tangan, telapak sampai pergelangan, dan telapak lengan. Untuk memudahkan pengelompokan, motif telapak tangan diberi tanda (I), motif telapak sampai pergelangan (II), dan motif telapak sampai lengan diberi tanda (III). 


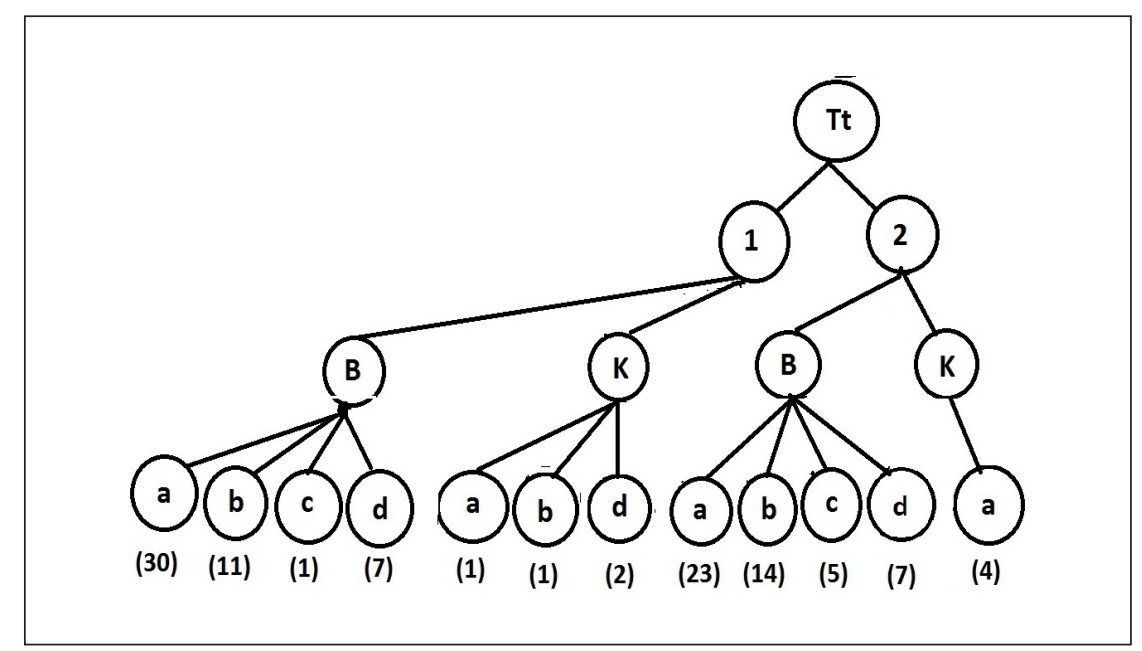

Bagan 3. Klasifikasi Taksonomik Motif Telapak Tangan Leang Uhallie.

Motif telapak tangan (I) pada Leang Uhallie berjumlah 103 yang terbagi menjadi motif telapak tangan kanan dan motif telapak tangan kiri. Motif telapak tangan kanan (1) pada Leang Uhallie terdiri dari (a) "Tt1Ba" (30), (b) "Tt1Ka" (2), (c) "Tt1Bb" (11), (d) "Tt1Kb" (1), (e) "Tt1Bc" (1), kemudian (f) "Tt1Bd" (7) dan (g) "Tt1 Kd" (2). Motif telapak tangan kiri (2) berjumlah 55 motif yang terdiri dari (a) "Tt2Ba" (23), (b) "Tt2Ka" (4), (c) "Tt2Bb" (14), (d) "Tt2Bc" (5), dan (e) "Tt2Bd" (7).

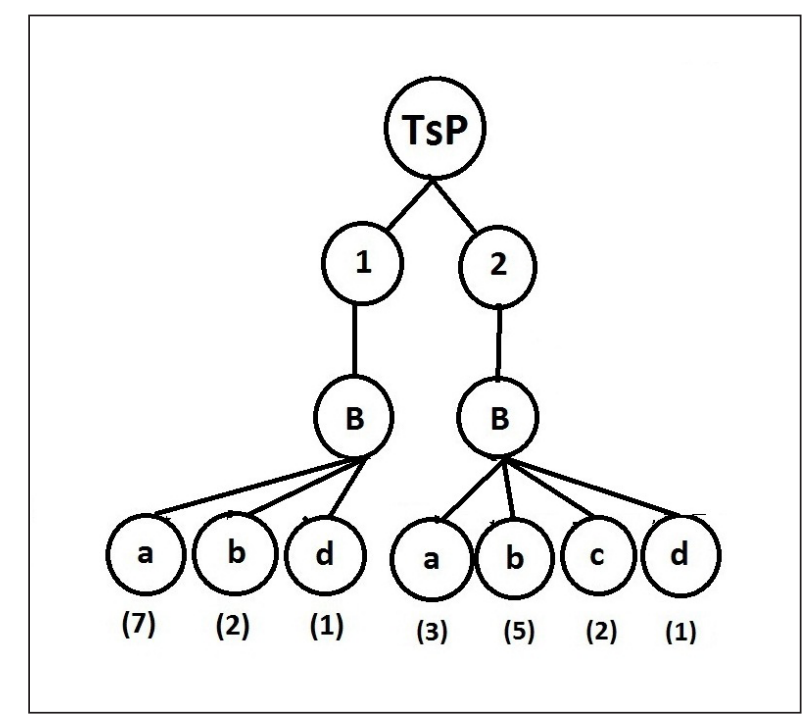

Bagan 4. Klasifikasi Taksonomik Motif Telapak sampai Pergelangan Leang Uhallie.

Sementara itu, motif telapak sampai pergelangan (II) di gua Uhallie berjumlah 21 yang terbagi menjadi motif telapak pergelangan tangan kanan dan motif telapak pergelangan tangan kiri. Motif telapak pergelangan tangan kanan (1) terdiri atas (a) "TsP1Ba" (7), (b) "TsP1Bb" (2), dan (c) "TsP1Bd" (1). Jumlah keseluruhan adalah 11 motif.

Motif telapak sampai pergelangan tangan kiri (2) juga sama jumlahnya, yaitu 11 motif yang terdiri atas (a) "TsP2Ba" (3), (b) "TsP2Bb" (5), kemudian (c) "TsP2Bc" (2), (d) "TsPBd" (1).

Selain motif telapak tangan dan telapak sampai pergelangan, motif lain adalah telapak sampai lengan (III) yang terdiri atas dua tipe yaitu "TsL2Ba" (1) dan "TsL2Bb" (1). Berikut ini bagan klasifikasinya. 


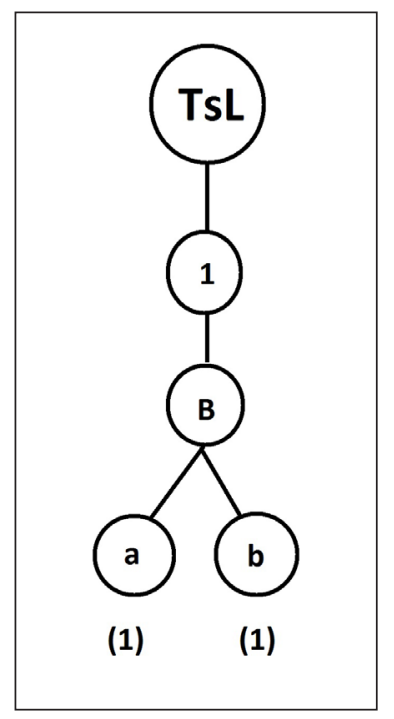

Bagan 5. Klasifikasi Taksonomik Motif Telapak sampai Lengan.

Diketahui bahwa setiap gambar motif tangan yang terdapat di tiap panil memiliki tipe bentuk yang bervariasi: keseluruhan motif tangan yang terdiri dari tiga tipe dengan 21 varian. Gambar tipe itu tentu berfrekuensi berbeda-beda pula, ada yang banyak dan ada pula yang sedikit. Dalam penelitian Permana mengenai gambar tangan gua prasejarah di Maros-Pangkep, Sulawesi Selatan, dijelaskan bahwa terdapat beberapa tipe gambar motif tangan. Namun, Permana (2014, 236-240) memperkecilnya menjadi dua tipe, yaitu tipe dominan dan tipe khas.

Perlu ditekankan bahwa pengelompokan motif tangan menjadi dua tipe dominan dan tipe khas tersebut dilakukan berdasarkan jumlah bentuk yang digambarkan di Leang Uhallie. Seperti yang telah diketahui, bentuk gambar motif tangan yang terdapat di gua itu adalah telapak tangan, telapak sampai pergelangan, dan telapak sampai lengan. Analisis bentuk motif tangan yang telah dilakukan di atas menunjukkan bahwa terdapat 125 motif tangan yang dapat dianalisis. Dari analisis itu dapat diketahui pula bahwa dari ratusan motif tangan yang ada, terdapat 102 motif telapak tangan yang terdiri atas 12 varian, 21 motif telapak sampai pergelangan yang terdiri atas 7 varian, dan dua motif telapak sampai lengan yang terdiri atas dua varian.

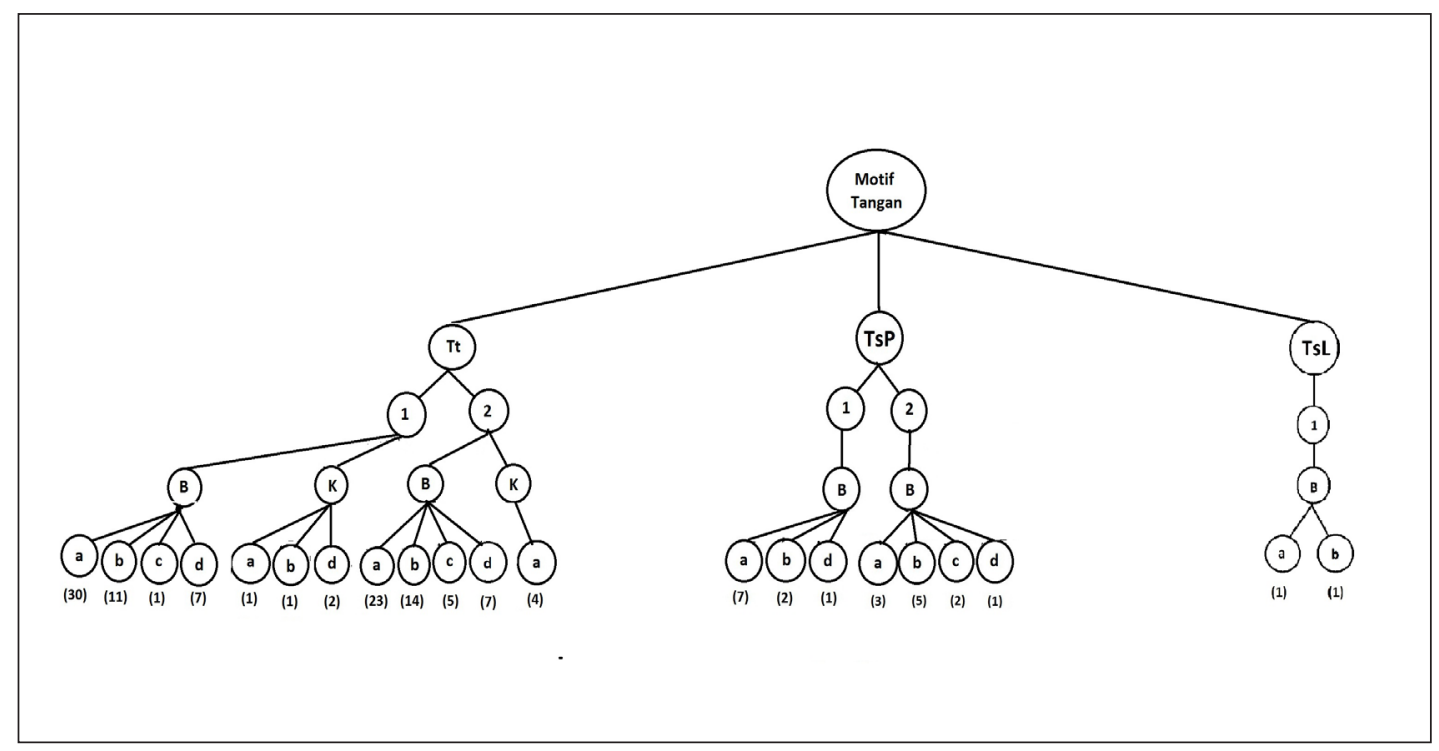

Bagan 6. Klasifikasi Taksonomik Motif Tangan di Leang Uhallie. 


\section{Kesimpulan}

Berdasarkan analisis bentuk dan klasifikasi, diketahui tipologi gambar cap tangan Leang Uhallie yang beragam tipe dan variasi. Motif tangan terdiri atas tiga tipe, yaitu tipe telapak tangan (I), telapak sampai pergelangan (II), dan telapak sampai lengan (III). Motif telapak tangan (I) terdiri atas 12 varian, yaitu telapak tangan kanan (1) berjumlah 54 motif yang terdiri dari (a) "Tt1Ba" (30), (b) "Tt1Ka" (2), (c) "Tt1Bb" (11), (d) "Tt1Kb" (1), (e) "Tt1Bc" (1), (f) "Tt1Bd" (7) dan (g) "Tt1Kd" (2). Motif telapak tangan kiri (2) berjumlah 55 motif yang terdiri atas (a) "Tt2Ba" (23), (b) "Tt2Ka" (4), (c)“Tt2Bb" (14), (d) "Tt2Bc" (5), dan (e) "Tt2Bd" (7). Telapak sampai pergelangan (II) yang berjumlah 21 motif dan terbagai atas dua tipe, yaitu 10 motif telapak pergelangan tangan kanan (1) yang terdiri atas (a) "TsP1Ba" (7), (b) "TsP1Bb" (2), dan (c) "TsP1Bd" (1), dan 11 motif telapak sampai pergelangan tangan kiri (2) yang terdiri atas (a) "TsP2Ba" (3), (b) "TsP2Bb" (4), (c) "TsP2Bc" (1), (d) "TsP2Ka" (1), (e) "TsP2Kb" (1), (f) "TsP2Kc" (1), dan "TsP2Kd" (1). Sementara itu, motif telapak sampai lengan (III) terdiri atas "TSL2Ba" (1) dan "TSL2Bb" (1).

Besaran jumlah bentuk gambar motif tangan di Leang Uhallie memperlihatkan bentuk motif yang dominan dan mana yang khas. Dari segi jumlah dan variasi tipe, motif tangan berbentuk telapak tangan dan telapak sampai pergelangan dapat dikategorikan sebagai motif dominan. Sementara itu, motif tangan berbentuk telapak sampai lengan dikategorikan sebagai motif khas karena kecilnya jumlah dan tipe yang digambarkan. Sifat bentuk motif tangan dapat pula dilihat dari letaknya dalam gua, seperti motif telapak tangan yang digambarkan di semua panil gua dan motif telapak sampai pergelangan yang digambarkan di Panil 2, Panil 4, dan Panil 5, menunjukkan bahwa kedua bentuk motif tangan itu dominan. Sementara itu, motif tangan berbentuk telapak sampai lengan hanya digambarkan di panil 2 dan panil 5 sehingga dapat dikategorikan motif yang khas.

Apabila mengacu kepada Permana (2014, 246-247), gua di Sulawesi Selatan pada umumnya didominasi oleh motif tangan yang berbentuk (Tt), bentuk (TsP) dan (TsL) hanya sedikit dan bahkan tidak ditemukan di beberapa gua. la meyakini bahwa jumlah kecil itulah yang menjadikan kedua motif itu bersifat khas dan kemungkinan memiliki makna dan tujuan tertentu yang bersifat khusus. Fakta itu membuktikan bahwa secara garis besar, manusia pendukung kebudayaan gambar cadas di Sulawesi Selatan memiliki pemikiran dan sudut pandang yang sama dalam penggambaran bentuk motif tangan di dalam gua.

\section{Daftar Referensi}

Arini, D.I.D. 2013. Anoa dan habitatnya di Sulawesi Utara. Manado: Balai Penelitian Kehutanan Manado.

Beck, C and Jones, G.T. 1989. Bias and archaeological classification, in American Antiquity 54 (2) Society for American Archaelogy.

Kosasih, E.A. 1983. Lukisan gua di Indonesia sebagai sumber data penelitian arkeologi. Dalam Pertemuan IImiah Arkeologi III. Jakarta: Pusat Arkeologi Nasional.

1999. Teknik analisis seni gua dan upaya pelestarian lingkungan karst, dalam Evaluasi hasil penelitian arkeologi. Bandung: Pusat Penelitian Arkeologi Nasional.

Maynard, L. 1977. Classification and terminology in Australian rock art. Dalam Ucko, P.J. (Ed.). Form in indigeneous art. Sidney: Australian Institute of Aboriginal Studies Canberra.

Permana, R. Cecep. 2014. Gambar tangan gua-gua prasejarah Pangkep-Maros-Sulawesi Selatan. Jakarta: Wedatama Widya Sastra.

Rosenfeld, A. 1988. Rock art in western Oceania, IPPA Bulletin 8: 119-138.

Rouse, I. 1971. The classifications of artifacts in archaeology. American Antiquity, XXV, 30, 313-323.

Sharer, R.J. dan Wendy, A. 2003. Archaeology discovering our past. New York : McGraw-Hill Companies.

Ucko, P.J., Ed. Form in indigeneous art. Sidney: Australian Institute of Aboriginal Studies Canberra. 